\title{
STRATEGI PENGOPTIMALAN PAKAN FERMENTASI DENGAN FORMULASI LIMBAH AMPAS TAHU TERHADAP PRODUKSI BUDIDAYA LELE DI DESA CANDISARI KECAMATAN SAMBENG KABUPATEN LAMONGAN
}

\author{
OPTIMIZE STRATEGIES FERMENTATION FEED WITH FORMULATION OF \\ WASTE OF TOFU TO PRODUCTION CULTIVATION OF LELE \\ IN CANDISARI VILLAGE SAMBENG SUB-DISTRICT LAMONGAN DISTRICT
}

\author{
Wachidatus Sa'adah*, Wulan Sari \\ Fakultas Perikanan Universitas Islam Lamongan \\ *E-mail: wachidaafandi@gmail.com \\ (Diterima 03-07-2018; Disetujui 20-07-2018)
}

\begin{abstract}
ABSTRAK
Penelitian ini dilakukan dengan tujuan untuk mengetahui teknis pembuatan pakan fermentasi dengan formulasi limbah ampas tahu dan strategi pengoptimalan pembuatannya terhadap produksi budidaya lele. Penelitian ini dilaksanakan di Desa Candisari Kecamatan Sambeng Kabupaten Lamongan. Metode yang digunakan dalam penelitian ini adalah metode kualitatif. Dari hasil penelitian bahwa pembuatan pakan fermentasi dengan formulasi limbah ampas tahu meliputi metode persiapan, bahan-bahan pembuatan dan proses pembuatan, sedangkan strategi pengoptimalannya adalah (a) peningkatan produksi pakan fermentasi dengan formulasi limbah ampas tahu; (b) pengembangan usaha dan mengenalkan pada masyarakat, bahwa pakan fermentasi dapat meningkatkan produksi budidaya ikan; (c) peningkatan produksi pakan fermentasi menjadi produk yang mempunyai nilai jual; (d) pengoptimalan limbah ampas tahu menjadi pakan alternatif.
\end{abstract}

Kata kunci: Pakan, Fermentasi, Ampas Tahu, Analisa SWOT.

\section{ABSTRACT}

This research was conducted with the aim to know the technical manufacture of fermented feed with the formulation of waste of tofu and optimization strategy of making to the production of catfish culture. This research was conducted in Candisari Village, Sambeng Sub-district, Lamongan District. The method used in this research is qualitative method. From the result of the research that the making of fermented feed with the formulation of waste of tofu waste includes preparation method, materials of manufacture and process of manufacture, while the optimization strategy is (a) increasing production of fermented feed with the formulation of waste of tofu waste; (b) business development and introduction to the community, that fermented feed can increase fish farming production; (c) increasing the production of fermented feeds into products of sale value; (d) optimizing the waste of tofu waste into alternative feed.

Keywords : Feed, Fermentation, Tofu, SWOT Analysis

\section{PENDAHULUAN}

Lele merupakan salah satu jenis ikan yang cukup digemari di Indonesia, kemampuannya yang mampu hidup dan bergerak lebih lama di luar air dibanding ikan yang lainnya. Lele memiliki ciri 


\section{Strategi Pengoptimalan Pakan Fermentasi dengan Formulasi Limbah Ampas Tahu Terhadap Produksi Budidaya Lele di Desa Candisari Kecamatan Sambeng Kabupaten Lamongan \\ Wachidatus Sa'adah, Wulan Sari}

tubuh yang licin, pipih memanjang serta memiliki kumis di sekitar mulutnya. Lele termasuk hewan omnivora yang cukup rakus juga bersifat kanibal sehingga akan membutuhkan cukup banyak pakan agar sifat kanibalnya tidak muncul, akibatnnya ongkos produksi juga meningkat. Untuk menyiasati hal tersebut, dibutuhkan pakan alternatif yang terjangkau namun memiliki cukup protein guna perkembangan lele dan mengurangi sifat kanibalismenya (Soedrijanto dan Sari, 2014).

Banyak cara yang telah dilakukan untuk mengurangi biaya pakan, Disamping itu pakan sebagai sumber nutrisi maupun energi merupakan bahan yang sangat menentukan dalam pencapaian kemampuan hidup suatu organisme. Menurut Nuraini (2009), ampas tahu dapat dijadikan sebagai pakan sumber protein karena mengandung protein kasar cukup tinggi yaitu $27,55 \%$ dan kandungan zat nutrien lain adalah lemak 4,93\%, serat kasar 7,11\%, BETN $44,50 \%$. Selain itu harga bahan, biaya produksi, dan proses produksinya terbilang murah. Pembuatan pakan ikan dengan ampas tahu dapat dilakukan melalui proses fermentasi. Salah satu upaya untuk mengefektifkan pemanfaatan enzim pencernaan adalah dengan pengaplikasian teknologi fermentasi pakan. Melalui fermentasi, dilakukan proses penguraian senyawa dari bahanbahan protein kompleks. Salah satu bahan pakan sumber protein yang perlu diteliti sebagai pakan alternatif adalah ampas tahu. Menurut Nugraheni (2007), ampas tahu masih layak dijadikan bahan pangan karena masih mengandung protein sekitar 5\%.

Ampas tahu merupakan limbah padat yang diperoleh dari proses pembuatan tahu dari kedelai. Sedangkan yang dibuat tahu adalah cairan atau susu kedelai yang lolos dari kain saring. Ditinjau dari komposisi kimianya ampas tahu dapat digunakan sebagai sumber protein, maka sangat memungkinkan ampas tahu dapat diolah menjadi bahan makanan ternak (Dinas Peternakan Provinsi Jawa Timur, 2011). Ampas tahu dalam bentuk aslinya dapat menimbulkan dampak atau permasalahan lingkungan karena hasil degradasinya dapat menimbulkan persenyawaan yang berbau busuk jika ampas tahu tidak dimanfaatkan. Barang limbah tidak selamanya merugikan atau tidak berguna. Hanya saja bagaimana kita dapat mensiasati limbah tadi menjadi sesuatu yang berguna. Salah satunya di Desa Candisari, di desa itu terdapat usaha 
home industry yang bergerak pada produksi tahu, akan tetapi limbah dari tahu tersebut jarang ada yang memanfaatkannya, sering kali limbah dianggap tidak memiliki nilai ekonomi sehingga sering dipandang sebelah mata oleh masyarakat umumnya. Hal ini dimanfaatkan oleh pelaku usaha untuk mengolah limbah ampas tahu tersebut menjadi pakan fermentasi. Selain memiliki protein yang tinggi untuk ikan, pakan alternatif dari ampas tahu ini juga dapat mengurangi biaya pakan dan menambah hasil produksi.

Berdasarkan latar belakang di atas, penulis melakukan penelitian tentang strategi pengoptimalan pakan fermentasi dengan formulasi limbah ampas tahu terhadap produksi budidaya lele di Desa Candisari Kecamatan Sambeng Kabupaten Lamongan.

Adapun tujuan dari penelitian ini adalah untuk mengetahui teknis pembuatan pakan fermentasi dengan formulasi limbah ampas tahu dan strategi pengoptimalan pembuatannya terhadap produksi budidaya lele.

\section{METODE PENELITIAN}

Metode yang digunakan dalam pelaksanaan penelitian ini adalah metode kualitatif dengan pengambilan sampel secara purposive sampling (Suharsimi, 2010), yaitu dengan sengaja mengambil sampel pada satu-satunya pelaku usaha pembuatan pakan fermentasi dari ampas tahu yang ada di Kabupaten Lamongan.

Teknik pengumpulan data yang digunakan terdiri atas dua macam, yaitu data primer dan data sekunder. Data primer diperoleh langsung dengan melakukan observasi, wawancara dan partisipasi aktif. Sedangkan data sekunder diperoleh melalui studi literatur, discovery learning melalui internet, dan lain-lain.

Analisis mengenai teknis pembuatan pakan fermentasi dengan formulasi limbah ampas tahu dilakukan secara deskriptif kualitatif, sedangkan strategi pengoptimalan pakan fermentasi dengan formulasi limbah ampas tahu terhadap produksi budidaya lele di Desa Candisari Kecamatan Sambeng Kabupaten Lamongan dilakukan dengan menggunakan analisis SWOT menurut Rangkuti (2014).

\section{HASIL DAN PEMBAHASAN}

\section{a. Teknik Pembuatan}

\section{Metode Persiapan}

Metode persiapan bertujuan untuk menyiapkan proses pembuatan pakan fermentasi dengan formulasi limbah 


\section{Strategi Pengoptimalan Pakan Fermentasi dengan Formulasi Limbah Ampas Tahu Terhadap Produksi Budidaya Lele di Desa Candisari Kecamatan Sambeng Kabupaten Lamongan \\ Wachidatus Sa'adah, Wulan Sari}

ampas tahu yang harus dipersiapkan yakni, mempersiapkan alat bahan baku untuk pembuatan pakan fermentasi.

\section{Bahan-bahan Pembuatan}

Bahan-bahan yang digunakan dalam proses fermentasi limbah pakan antara lain ampas tahu, tepung ikan, tepung jagung, bungkil kedelai, bungkil kelapa, bungkil kacang, dedak halus, pollard, pro-biotik, tetes tebu dan air.

\section{Proses Pembuatan}

Proses pemasakan bertujuan untuk menjadikan bahan baku menjadi bahan jadi, alur proses pembuatannya dijelaskan sebagai berikut:

(1) $100 \mathrm{~kg}$ bahan dicampur sesuai formulasi hingga homogen.

(2) Ditambahkan 1 liter probiotik.

(3) Ditambahkan tetes 3 liter + air 1 liter.

(4) Dilakukan fermentasi selama \pm 5 hari dalam kantong tertutup (kedap udara).

(5) Dihindarkan dari sinar matahari langsung.

Teknik pembuatan pakan fermentasi dengan formulasi limbah ampas tahu dilakukan dengan cara menggunakan probiotik, yaitu suatu cara pengolahan melalui proses pemanfaatan penguraian senyawa dari bahan-bahan yang berprotein komplek. Bahan-bahan dari probiotik dapat dilihat pada Tabel 1 .
Pakan dari hasil fermentasi baru bisa digunakan dalam jarak waktu 7 hari. Namun apabila ingin mempercepat hasil fermentasi bisa disiasati dengan menambah jumlah takaran pada probiotik dengan selisih tambahan 20-30\% penambahan probiotik dapat mempercepat 3-4 hari, sehingga proses fermentasi bisa lebih cepat.

Keuntungan menggunakan pakan fermentasi dengan menggunakan formulasi limbah ampas tahu dibandingkan dengan menggunakan pakan pellet yaitu dapat dilihat dari biaya yang dikeluarkan untuk pakan dan hasil produksi yang diperoleh pada setiap siklusnya.

Dengan padat tebar yang sama pembudidaya lele yang menggunakan pakan fermentasi dengan formulasi limbah ampas tahu menghabiskan biaya pakan sebesar Rp 5.105.000 dalam 3 bulan, dan hasil produksinya adalah 810 $\mathrm{kg}$, sedangkan pembudidaya lele yang menggunakan pakan pellet menghabiskan biaya pakan sebesar Rp 6.130.000 dalam 3 bulan, dan hasil produksinya adalah $760 \mathrm{~kg}$. Dari penjabaran di atas, dapat diketahui bahwa pakan fermentasi dengan formulasi limbah ampas tahu, bisa lebih hemat dan berpengaruh 
terhadap peningkatan produksi budidaya

lele.

\section{Tabel 1. Komposisi Pembuatan Probiotik}

\begin{tabular}{clcl}
\hline No & \multicolumn{1}{c}{ Bahan } & Jumlah & \multicolumn{1}{c}{ Kegunaan } \\
\hline 1 & Jahe Merah & $0,5 \mathrm{~kg}$ & $\begin{array}{l}\text { Sebagai pestisida nabati dan untuk menstabilkan } \\
\text { ketahanan tubuh. }\end{array}$ \\
\hline 2 & Kunyit Putih & $1 \mathrm{~kg}$ & $\begin{array}{l}\text { Sebagai penambah nafsu makan dan segala jenis } \\
\text { makanan tidak ditolak dalam pencernaan sehingga } \\
\text { tetap bisa dicerna secara sempurna, sehingga } \\
\text { limbah atau kotoran tetap aman dan bisa menjadi } \\
\text { plankton positf. }\end{array}$ \\
\hline 3 & Temulawak & $1,5 \mathrm{~kg}$ & $\begin{array}{l}\text { Sebagai penambah nafsu makan dan segala jenis } \\
\text { makanan tidak ditolak dalam pencernaan sehingga } \\
\text { tetap bisa dicerna secara sempurna, sehingga }\end{array}$ \\
\hline 4 & Gula Merah & $2,5 \mathrm{~kg}$ & $\begin{array}{l}\text { limbah atau kotoran tetap aman dan bisa menjadi } \\
\text { plankton positf. }\end{array}$ \\
\hline 5 & Susu Segar & $1 \mathrm{liter}$ & \begin{tabular}{l} 
Sebagai makanan bakteri. \\
\hline 6
\end{tabular} Tetes Tebu \\
\hline 7 & Dedak Halus & $0,5 \mathrm{~kg}$ & $\begin{array}{l}\text { Sebagai makanan utama setelah bakteri terbentuk } \\
\text { dan berkembang. }\end{array}$ \\
\hline 8 & Markisa/ Nanas & $0,5 \mathrm{~kg}$ & $\begin{array}{l}\text { Untuk menghilangkan dan mencegah bau kotoran } \\
\text { atau pencemaran lainnya. }\end{array}$ \\
\hline $\begin{array}{l}\text { Mengandung vitamin C, yang berfungsi sebagai } \\
\text { daya tahan tubuh atau kekebalan tubuh, agar tahah } \\
\text { dalam segala kondisi cuaca. }\end{array}$
\end{tabular}

Sumber: Data Primer, 2017

\section{b. Analisa Pengoptimalan Proses Fermentasi}

Analisa SWOT terdiri atas analisis internal dari permasalahan meliputi kekuatan dan kelemahan dan analisis eksternal berupa peluang dan ancaman dari luar. Secara garis besar faktor-faktor internal strategi pengoptimalan pakan fermentasi dengan formulasi limbah ampas tahu di Desa Candisari diantaranya meliputi:

\section{Kekuatan}

a. Bahan baku harganya dapat dijangkau; b. Bahan baku berkualitas;

c. Bahan tambahan yang mudah diperoleh;

d. Bahan pembantu untuk mempercepat proses fermentasi pakan;

e. Ampas tahu memiliki protein tinggi, sehingga baik untuk pertumbuhan ikan.

2. Kelemahan

a. Tempat produksi kurang luas, sehingga tidak dapat memproduksi pakan dalam jumlah banyak; 
Strategi Pengoptimalan Pakan Fermentasi dengan Formulasi Limbah Ampas Tahu Terhadap Produksi Budidaya Lele di Desa Candisari Kecamatan Sambeng Kabupaten Lamongan

Wachidatus Sa'adah, Wulan Sari

b. Pengolahan masih menggunakan mesin manual;

c. Peralatan yang digunakan terbatas;

d. Pembuatan pakan harus sesuai dengan prosedur, karena bisa berpengaruh pada kualitas yang dihasilkan.

Sedangkan faktor-faktor eksternal strategi pengoptimalan pakan fermentasi dengan formulasi limbah ampas tahu di Desa Candisari diantaranya meliputi:

1. Peluang

a. Pakan fermentasi bisa menggantikan pakan pellet;

b. Masih jarang yang mengolah limbah ampas tahu;

c. Bisa masuk pasar, karena harga yang ditawarkan lebih murah dari harga pakan pallet.

2. Ancaman

a. Ketersediaan bahan baku tergantung dengan musim;

b. Peternak sapi menggunakan ampas tahu sebagai pakan ternak, sehingga mengakibatkan jumlah ampas tahu tidak bisa maksimal; c. Tingkat inflasi .

Dengan mengetahui kekuatankelemahan dan peluang-ancaman yang dihadapi oleh usaha pengolahan limbah ampas tahu di Desa Candisari ini, maka dapat dilakukan proses pengambilan keputusan strategi yang selalu berkaitan dengan latar belakang, potensi dan permasalahan yang ada, sehingga dengan kekuatan yang dimilikinya diharapkan produsen dapat memanfaatkan peluang yang ada dan dapat meminimalkan kelemahan dan ancamannya.

\section{c. Analisa SWOT untuk Strategi Pengoptimalan Limbah Ampas Tahu}

Untuk melakukan analisa SWOT ini perlu dilakukan data-data yang sesuai dengan usaha pengolahan pakan limbah ampas tahu di Desa Candisari. Data yang diperoleh dari hasil wawancara langsung dengan pembudidaya lele dengan menggunaan pakan alternatif dengan formulasi limbah ampas tahu ini, sebagai data primer. Adapun matriks yang memuat hasil analisa SWOT dan nilai bobotnya disajikan pada Tabel 2 dan 3 . 
Tabel 2. Faktor Strategi Internal

\begin{tabular}{|c|c|c|c|}
\hline Faktor-faktor Internal & Bobot & Rating & $\begin{array}{c}\text { Skor } \\
\text { Pembobotan }\end{array}$ \\
\hline \multicolumn{4}{|l|}{ Kekuatan (S) } \\
\hline 1. Bahan baku harganya dapat dijangkau & 0.05 & 4 & 0.20 \\
\hline 2. Bahan baku berkualitas & 0.11 & 3 & 0.33 \\
\hline 3. Bahan tambahan yang mudah diperoleh & 0.07 & 4 & 0.28 \\
\hline $\begin{array}{l}\text { 4. Bahan pembantu untuk mempercepat proses } \\
\text { fermentasi pakan }\end{array}$ & 0.15 & 3 & 0.45 \\
\hline $\begin{array}{l}\text { 5. Ampas tahu memiliki protein tinggi, sehingga baik } \\
\text { untuk pertumbuhan ikan }\end{array}$ & 0.13 & 3 & 0.39 \\
\hline Total Kekuatan & 0.51 & & 1.65 \\
\hline \multicolumn{4}{|l|}{ Kelemahan (W) } \\
\hline $\begin{array}{l}\text { 1. Tempat produksi kurang luas, sehingga tidak dapat } \\
\text { memproduksi pakan dalam jumlah banyak }\end{array}$ & 0.15 & 2 & 0.30 \\
\hline 2. Pengolahannya masih menggunakan mesin manual & 0.9 & 3 & 0.27 \\
\hline 3. Peralatan yang digunakan terbatas & 0.10 & 2 & 0.20 \\
\hline $\begin{array}{l}\text { 4. Pembuatan pakan harus sesuai dengan prosedur, } \\
\text { karena bisa berpengaruh pada kualitas yang dihasilkan }\end{array}$ & 0.15 & 2 & 0.30 \\
\hline Total Kelemahan & 0.49 & & 1.07 \\
\hline Total & 1.00 & & 2.72 \\
\hline
\end{tabular}

Sumber: Data Primer, 2017

Tabel 3. Faktor Strategi Eksternal

\begin{tabular}{|c|c|c|c|}
\hline Faktor-faktor Internal & Bobot & Rating & $\begin{array}{c}\text { Skor } \\
\text { Pembobotan } \\
\end{array}$ \\
\hline \multicolumn{4}{|l|}{ Peluang (O) } \\
\hline 1. Pakan fermentasi bisa menggantikan pakan pellet & 0.15 & 3 & 0.45 \\
\hline 2. Masih jarang yang mengolah limbah ampas tahu & 0.17 & 2 & 0.35 \\
\hline $\begin{array}{l}\text { 3. Bisa masuk pasar, karena harga yang ditawarkan lebih } \\
\text { murah dari harga pakan pallet }\end{array}$ & 0.20 & 3 & 0.60 \\
\hline Total Peluang & 0.52 & & 1.40 \\
\hline \multicolumn{4}{|l|}{ Ancaman $(\mathrm{T})$} \\
\hline \\
\hline $\begin{array}{l}\text { 2. Peternak sapi menggunakan ampas tahu sebagai pakan } \\
\text { ternak, sehingga mengakibatkan jumlah ampas tahu }\end{array}$ & 0.20 & 2 & 0.40 \\
\hline & 0.15 & 3 & 0.45 \\
\hline 3. Tingkat inflasi & 0.13 & 3 & 0.36 \\
\hline Total Ancaman & 0.50 & & 1.24 \\
\hline Total & 1.00 & & 2.65 \\
\hline
\end{tabular}

Sumber: Data Primer, 2017 
Strategi Pengoptimalan Pakan Fermentasi dengan Formulasi Limbah Ampas Tahu Terhadap Produksi Budidaya Lele di Desa Candisari Kecamatan Sambeng Kabupaten Lamongan

Wachidatus Sa'adah, Wulan Sari

d. Bagan Analisa SWOT untuk

\section{Strategi Pengoptimalan Limbah}

Ampas Tahu

Selain menggunakan matriks IFAS dan EFAS, perencanaan strategi usaha budidaya lele di Desa Candisari Kecamatan Sambeng Kabupaten Lamongan dengan memanfaatkan limbah ampas tahu sebagai pakan alternatif ini juga dapat dilakukan menggunakan bagan SWOT sebagimana terlihat pada Gambar 1.

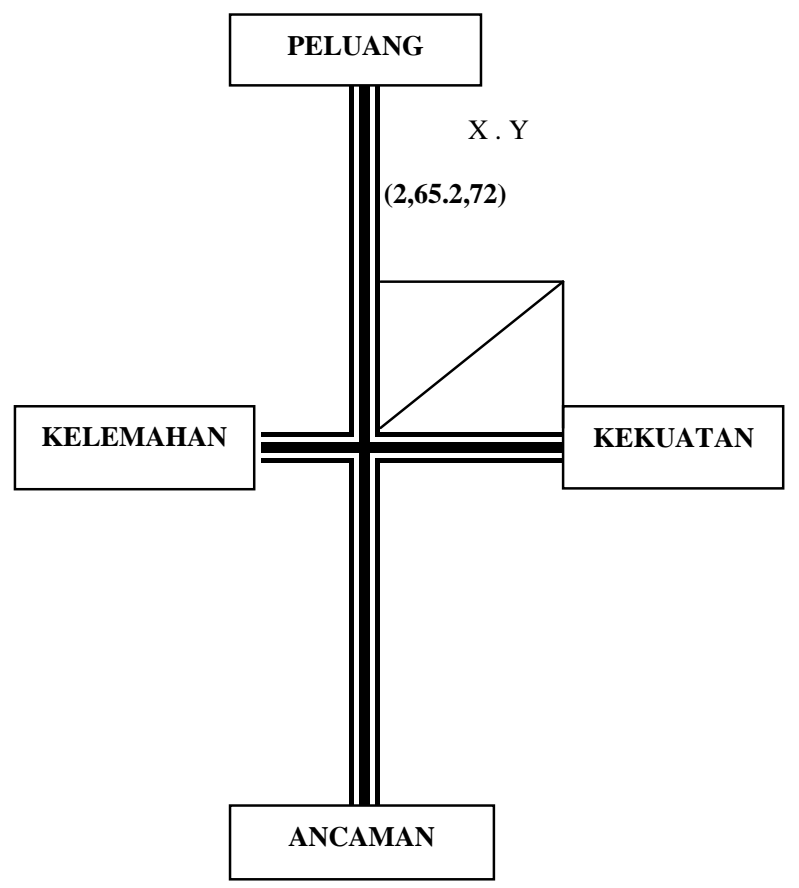

Gambar 1. Bagan SWOT
Dilihat dari Gambar 1 di atas, hasil dari IFAS 2,72 dan EFAS 2,65 menunjukkan pada kolom strategi agresif. Hal ini menujukkan bahwa dalam usaha budidaya ikan lele dengan menggunakan pakan alternatif dari limbah ampas tahu ini dalam situasi sangat mendukung, memiliki peluang dan kekuatan untuk memanfaatkan peluang yang ada dengan sebaik-baiknya.

\section{e. Matrik SWOT untuk Strategi Pengoptimalan Limbah Ampas Tahu}

Penyusunan strategi usaha budidaya lele di Desa Candisari Kecamatan Sambeng Kabupaten Lamongan dengan memanfaatkan limbah ampas tahu sebagai pakan alternatif dilakukan dengan cara membandingkan faktor-faktor internal dan eksternal dengan memberikan peringkat strategi dari tiap sel yang dihasilkan dari matrik SWOT sebagaimana terlihat pada Tabel 4. 
Tabel 4. Matrik Kekuatan - Kelemahan dan Peluang Ancaman SWOT

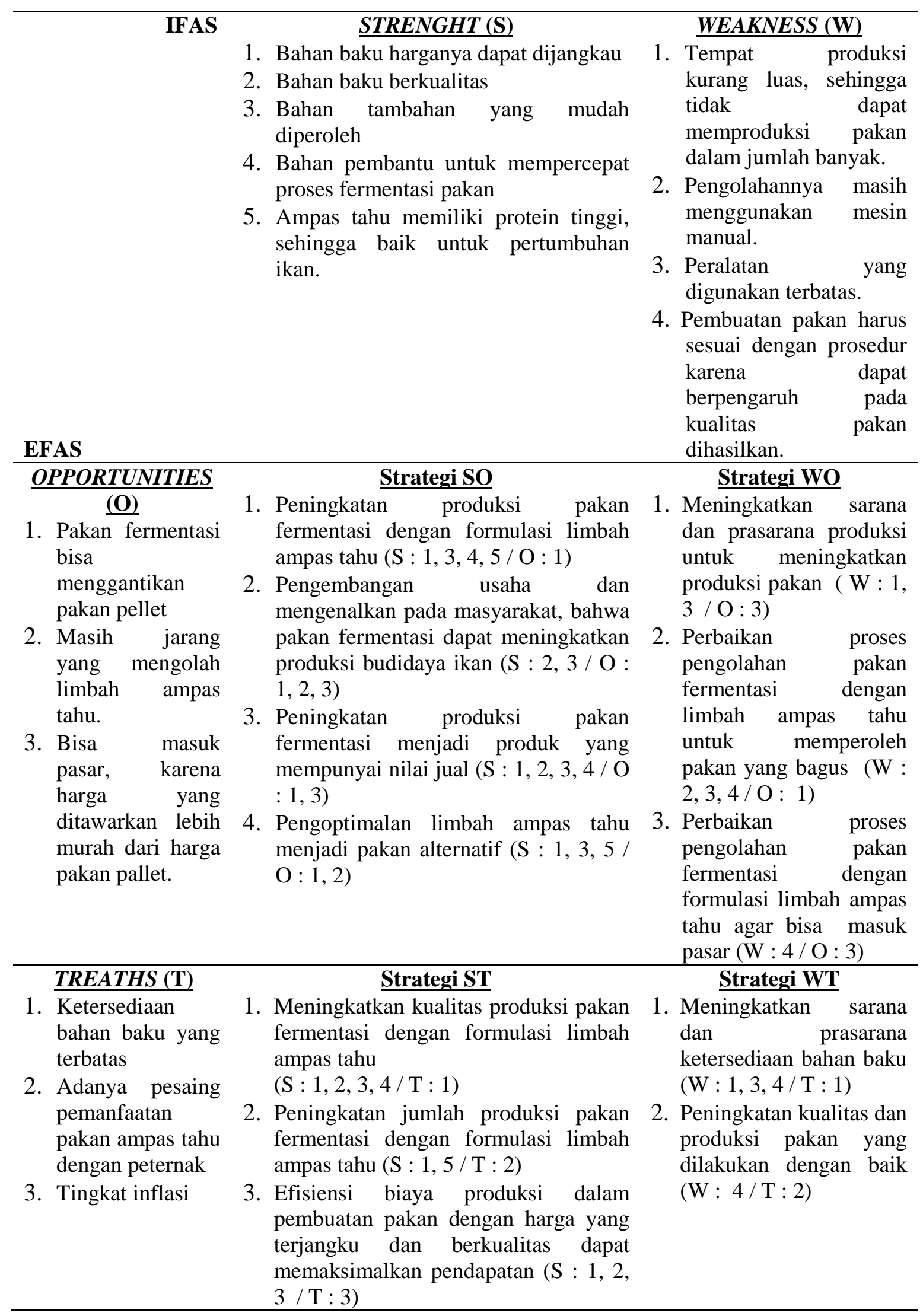


Strategi Pengoptimalan Pakan Fermentasi dengan Formulasi Limbah Ampas Tahu Terhadap

Produksi Budidaya Lele di Desa Candisari Kecamatan Sambeng Kabupaten Lamongan

Wachidatus Sa'adah, Wulan Sari

\section{PENUTUP}

Proses pembuatan pakan fermentasi dengan formulasi limbah ampas tahu meliputi: metode persiapan, bahan-bahan pembuatan dan proses pembuatan.

Strategi pengoptimalan dari limbah ampas meliputi:

(1) Peningkatan produksi pakan fermentasi dengan formulasi limbah ampas tahu.

(2) Pengembangan usaha dan mengenalkan pada masyarakat, bahwa pakan fermentasi dapat meningkatkan produksi budidaya ikan;

(3) Peningkatan produksi pakan fermentasi menjadi produk yang mempunyai nilai jual;

(4) Pengoptimalan limbah ampas tahu menjadi pakan alternatif.

Alur produksi dan fasilitas-fasilitas produksi sudah bagus tapi masih perlu diperhatikan dan diperbaiki dan perlu ditingkatkan kembali. Kemudian memperluas jaringan promosi agar produk olahan pakan fermentasi bisa masuk pasar dan memperluas kembali jaringan industri tahu, agar tidak tergantung pada satu industri tahu, jadi pakan fermentasi bisa diupayakan secara terus-menerus.

\section{DAFTAR PUSTAKA}

Dinas Peternakan Propinsi Jawa Timur. 2011. Uji Coba Pembuatan Silase Ampas Tahu. Surabaya.

Nugraheni, M. 2007. Pengaruh ekstrak kecambah kacang hijau sebagai sumber nitrogen pada pemanfaatan limbah tahu terhadap karakteristik nata de soya mentah dan limbahnya. Jurnal Tekhnologi dan Kejuruan, Volume 30 Nomor 2.

Nuraini. 2009. Performa Broiler dengan Ransum Mengandung Campuran Ampas Sagu dan Ampas Tahu yang Difermentasi dengan Neurospora Crassa. Media Peternakan, 32(3): 196-203.

Rangkuti, F. 2014. Analisis SWOT Teknis Membedah Kasus Bisnis Cara Perhitungan Bobot, Rating dan OCAI. Jakarta: PT Gramedia Pustaka Utama.

Sa'adah, W. 2014. Strategi Pengembangan Usaha Ikan Lele Asap dan Ikan Pari Asap di KUB Mina Barokah Desa Kabalan Kecamatan Kanor Kabupaten Bojonegoro. Grouper Faperik, 1 April 2014: 37-47.

Soedrijanto, A. dan Sari, W. 2014. Konstribusi Pakan dengan Formulasi Ampas Tahu pada Pembesaran Ikan Lele Sangkuriang Terhadap Pendapatan Pembudidaya di Desa Candisari Kecamatan Sambeng Kabupaten Lamongan. Grouper Jurnal Ilmiah Fakultas Perikanan, 1-4.

Suharsimi, A. 2010. Prosedur Penelitian Suatu Pendekatan Praktik. Jakarta: Rineka Cipta. 